DE

M E D I C I N A

T R O P I C A L

$\mathrm{DE}$

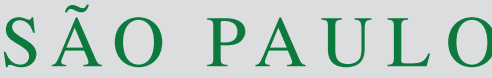

JOURNAL OF THE SÃO PAULO INSTITUTE OF TROPICAL MEDICINE

${ }^{1}$ Administración Nacional de Laboratorios e Institutos de Salud "Dr. Carlos G. Malbrán”, Centro Nacional de Diagnóstico e Investigación en Endemoepidemias, Buenos Aires, Argentina

${ }^{2}$ Instituto Universitario de Ciencias de la Salud Fundación Héctor A. Barceló, Facultad de Medicina, Laboratorio de Vectores, Santo Tomé, Corrientes, Argentina

${ }^{3}$ Consejo Nacional de Investigaciones Científicas y Técnicas, Buenos Aires, Argentina

${ }^{4}$ Universidad de Buenos Aires, Facultad de Ciencias Exactas y Naturales, Departamento de Ecología, Genética y Evolución, Buenos Aires, Argentina.

Correspondence to: Arturo A. Lizuain Administración Nacional de Laboratorios e Institutos de Salud "Dr. Carlos G. Malbran", Centro Nacional de Diagnóstico e Investigación en Endemoepidemias, Av. Paseo Colón, 568, $1^{\text {er }}$ piso, CABA, 1063, Buenos Aires, Argentina

E-mail: arlizuain@gmail.com

Received: 3 December 2018

Accepted: 14 January 2019

\section{Update on the distribution of Aedes albopictus (Diptera: Culicidae) in Misiones, Argentina}

\author{
Arturo A. Lizuain ${ }^{\circledR 1}$, Marina Leporace ${ }^{\circledR}$ 2, María Soledad Santini ${ }^{(1,3}$,
} María Eugenia Utgés ${ }^{\circledR}$, Nicolás Schweigmann ${ }^{\circledR 3,4}$

\section{ABSTRACT}

The Asian tiger mosquito (Aedes albopictus, Diptera: Culicidae) has spread rapidly in the last 30 years from its native region in Southeast Asia. In Argentina, studies on its potential distribution suggest that this species could be found in temperate zones of the province of Buenos Aires. However, since its initial detection in 1998 Ae. albopictus is bounded to the subtropical province of Misiones. To evaluate the presence and abundance of Ae. albopictus in the Northeast of Argentina, we preliminarily evaluated the presence of this vector by analyzing its presence in tires of 20 cities belonging to the province of Misiones and four cities in Northern Corrientes, and then performed an evaluation of the vector in the towns where the vector was detected. Aedes albopictus was present only in two cities of Misiones: Eldorado and Colonia Aurora. Aedes aegypti and Ae. albopictus accounted for $86 \%$ of the individuals collected in the domiciles of both towns. In Colonia Aurora both species were in similar abundances suggesting a co-dominance. The present study extends the austral distribution of Ae. albopictus in Argentina to the city of Colonia Aurora where the highest abundance recorded in Argentina was detected. Nevertheless, the reasons of its bounded distribution in the region are not known.

KEYWORDS: Mosquitoes. Tires. Vector. Aedes aegypti. Ae. albopictus. Asian tiger mosquito. Diptera: Culicidae. Distribution. Arboviruses.

\section{INTRODUCTION}

In the world, the Asian tiger mosquito Aedes albopictus (Skuse, 1894) (Diptera: Culicidae) is a competent vector for at least 22 arboviruses. These include chikungunya and the four serotypes of dengue virus, mainly transmitted by Ae. aegypti ${ }^{1}$.

This species has spread rapidly in the last 30 years from its native region in Southeast Asia. It is an invasive mosquito whose dry-resistant eggs have facilitated its transport to other continents through used tires and other artificial containers ${ }^{1,2}$. At present, this mosquito is well established in different parts of North and South America, Southern Europe, and islands of Oceania and part of Africa ${ }^{3}$.

Aedes albopictus was discovered almost simultaneously in the United States and Brazil in the mid $1980 \mathrm{~s}^{2}$. This species had previously been detected in tire shipments in North American ports and in a Tennessee cemetery. The Northern limit of this species corresponds roughly to the $-5{ }^{\circ} \mathrm{C}$ isotherm, as predicted by cold-resistance studies ${ }^{3}$. The species entered Florida in 1986, from the temperate North and had already colonized all Florida counties by 1994, coinciding with a decline in Ae. aegypti's population ${ }^{2}$. 
In Central and South America, this species was reported in 16 countries or islands ${ }^{4,5}$. In Brazil, 24 out of 27 States are already colonized ${ }^{6}$, but in Argentina, Ae. albopictus is bounded to the province of Misiones since its discovery in $1998^{7}$. Adult, pupae and larvae were recorded at Iguazu National Park and in the cities of San Antonio, Eldorado, Puerto Iguazu and Comandante Andresito ${ }^{7-9}$ (Figure 1). In 1998, the only ecological study to date reported a relative low abundance when compared to Ae. aegypti $(\approx 1: 10)$ in the municipality of Eldorado, and described that larvae and pupae of both species were collected in the same artificial breeding sites $^{8}$.

To date, studies have described that Ae. albopictus predominates in rural areas and Ae. aegypti in highly urbanized habitats, while both are present in suburban $\operatorname{areas}^{10}$. This pattern was proposed as a promoter of the coexistence between species, avoiding direct competition.

Since its dispersion across the world occurred passively through transport and commercial exchange of used tires with presence of preimaginal stages and eggs, the present work has preliminarily evaluated the presence of this vector in tires of different districts of the province of Misiones and Northern of Corrientes; then evaluated the vector in the houses of the cities where its presence was detected.

\section{MATERIALS AND METHODS}

\section{Study area}

We sampled 20 cities of the province of Misiones and four in the North of the province of Corrientes (Figure 1, Table 1). The study area has a subtropical climate, with

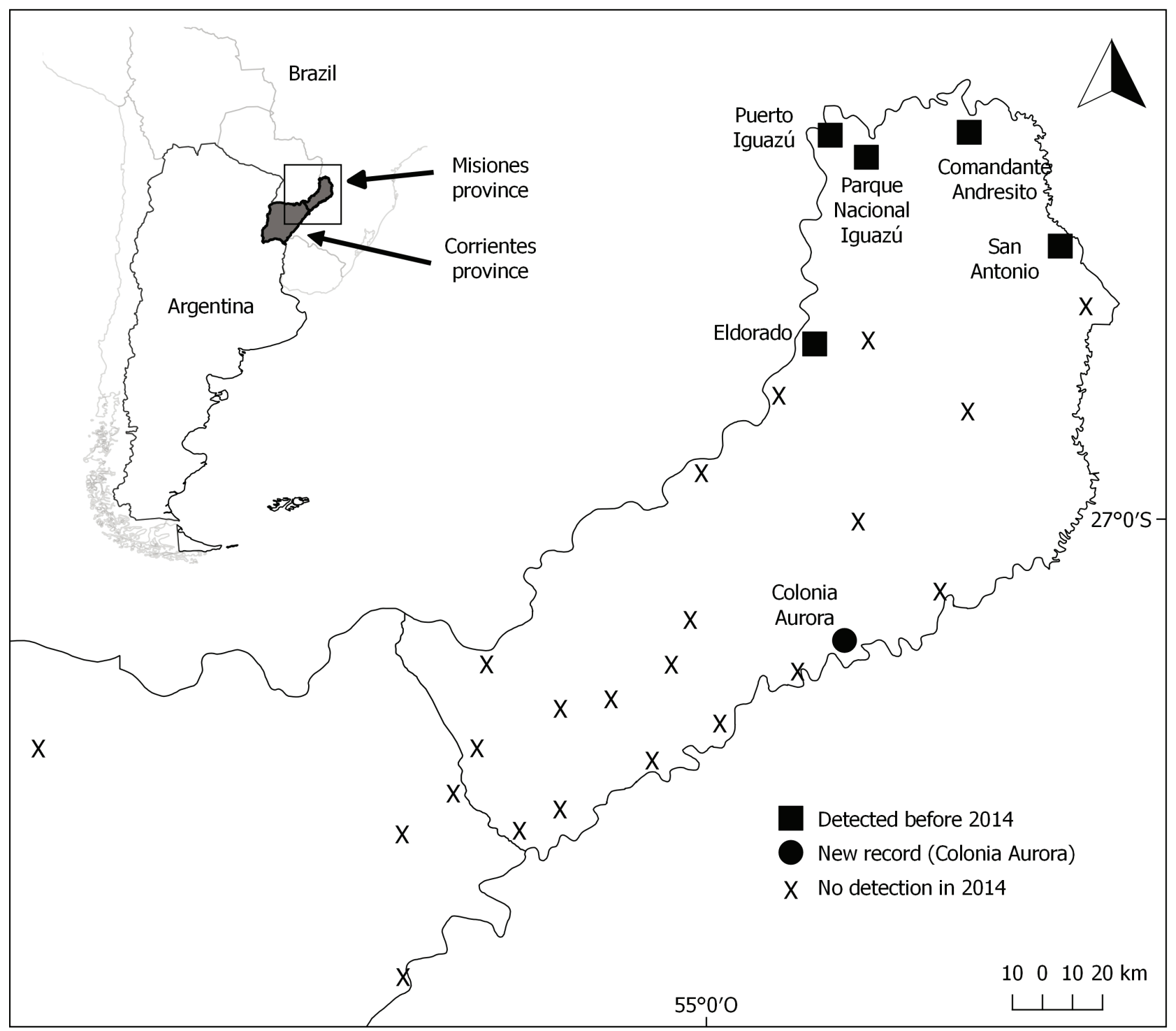

Figure 1 - Location of the province of Misiones and Corrientes in Argentina (upper left). Cities evaluated in 2014 and records with presence of $\mathrm{Ae}$. albopictus in the province of Misiones. 
Table 1 - Mosquitoes captured by species in the cities surveyed in 2014.

\begin{tabular}{|c|c|c|c|c|c|c|c|c|c|}
\hline City & $\begin{array}{l}\text { Human } \\
\text { population }\end{array}$ & $\begin{array}{c}\text { \# Tire } \\
\text { deposits }\end{array}$ & $\begin{array}{c}\text { Tires with } \\
\text { larval stages }\end{array}$ & $A E G$ & QUI & FLU & $\mathrm{BIG}$ & ALB & Total \\
\hline ED & 63,931 & 4 & 18 & 146 & 64 & 49 & 4 & 2 & 287 \\
\hline ES & 22,898 & 4 & 8 & 5 & 179 & 3 & 5 & & 196 \\
\hline LA & 31,051 & 2 & 15 & 93 & 19 & 59 & 10 & & 185 \\
\hline SL & 1,950 & 1 & 4 & 5 & 2 & 8 & 1 & & 17 \\
\hline $\mathrm{BI}$ & 13,768 & 3 & 7 & 12 & 5 & 38 & 6 & & 71 \\
\hline SP & 31,051 & 3 & 16 & 110 & 7 & 20 & 2 & & 143 \\
\hline SV & 44,999 & 3 & 6 & 16 & 29 & 2 & 1 & & 48 \\
\hline VI & 32,983 & 1 & 12 & 16 & 39 & 126 & & & 182 \\
\hline$A Z$ & 4,113 & 2 & 3 & 3 & 1 & 2 & & & 22 \\
\hline $\mathrm{CN}$ & 14,181 & 1 & 6 & 8 & 3 & 68 & & & 80 \\
\hline AP & 7,098 & 1 & 2 & 6 & 42 & 1 & & & 49 \\
\hline JA & 13,030 & 2 & 4 & 23 & 1 & 42 & & & 66 \\
\hline LO & 3,012 & 1 & 11 & 20 & 36 & 1 & & & 57 \\
\hline $\mathrm{CV}$ & 10,078 & 3 & 9 & 40 & 19 & 4 & & & 63 \\
\hline $\mathrm{MO}$ & 24,338 & 1 & 5 & 35 & 13 & & & & 56 \\
\hline$C L$ & 3,900 & 1 & 2 & 4 & 1 & & & & 5 \\
\hline JO & 7,095 & 2 & 2 & 15 & 8 & & & & 23 \\
\hline ST & 25,824 & 2 & 3 & 4 & 3 & & & & 14 \\
\hline PR & 19,500 & 1 & 2 & 10 & & 6 & & & 20 \\
\hline CS & 7,988 & 1 & 2 & 4 & & 12 & & & 16 \\
\hline$C Z$ & 5,854 & 1 & 1 & 14 & & & & & 14 \\
\hline $\mathrm{CA}$ & 7,744 & 5 & 18 & & 41 & 29 & 8 & 37 & 138 \\
\hline PA & 5,928 & 1 & 2 & & 5 & 4 & 2 & & 11 \\
\hline $\mathrm{OB}$ & 66,112 & 1 & 4 & & & 8 & 1 & & 9 \\
\hline Total & & 47 & 162 & 589 & 517 & 482 & 40 & 39 & 1,772 \\
\hline
\end{tabular}

From Misiones: Alba Posse (AP), Azara (AZ), Bernardo de Irigoyen (BI), Candelaria (CN), Cerro Azul (CZ), Colonia Aurora (CA), Concepcion de la Sierra (CS), Campo Viera (CV), Eldorado (ED), El Soberbio (ES), San Javier (JA), San Jose (JO), Leandro N. Alem (LA), Montecarlo (MO), Obera (OB), Panambi (PA), Puerto Rico (PR), Santiago de Liniers (SL), San Pedro (SP), San Vicente (SV). From Corrientes: Colonia Liebig (CL), Loreto (LO), Santo Tome (ST), Gobernador Ingeniero Valentin Virasoro (VI). Human population according to Ministerio del Interior22; number of specimens of the most abundant species: Ae. aegypti (AEG), Ae. fluviatilis (FLU), Cx. quinquefasciatus (QUI), Lt. bigoti (BIG), Ae. albopictus (ALB).

precipitations throughout the year (from $1564 \mathrm{~mm}$ to $2012 \mathrm{~mm}$, annually). The average annual temperature varies between 20 and $21^{\circ} \mathrm{C}$, with mild winters (phytogeographical region: Parana Province, Amazonian Domain) ${ }^{11}$.

\section{Collection and analysis of data}

In January 2014, we collected preimaginal stages present in the study area (Figure 1, Table 1). We evaluated 5-30 tires per tire deposit in each city ( 1 to 5 deposits/ city). Up to a total of five deposits were examined in each city, providing that no larvae were found at the first deposit (in some of the cities all deposits available were sampled $)^{12}$.
Pre-imaginal stages were collected and fixed in situ with alcohol $70 \%$.

In March 2015, samples were collected from 50 houses with breeding sites in the towns of Colonia Aurora (20) and Eldorado (30) (Misiones, Figure 1). In Colonia Aurora, sampling was carried out throughout the village. As Eldorado has a greater extension (Table 1), the city was stratified into two areas: one urban and one peri-urban. In each zone, samples were taken from 13 and 17 houses, respectively. All the houses were selected according to the criteria of accessibility and the informed consent of all the owners of the houses was obtained with the approved consent of the Ethics Commission. 
Only artificial containers with water in the peridomicile of the houses were examined. Each artificial breeding site was classified according to the type of container. Mosquito larvae were collected by filtration and fixation in alcohol $70 \%$. All specimens collected were transported to the laboratory, examined under a stereoscopic microscope and specimens were identified at the species level ${ }^{13}$.

To evaluate the existence of independence between towns, a Pearson's Chi-squared test was performed using Infostat with the relative abundances of Ae. aegypti (Linnaeus,1762), Ae. albopictus and the rest of the collected species.

\section{Comparison with Eldorado in 1998}

In order to compare this study with the situation of $A e$. albopictus in Eldorado observed in $1998^{8}$, we compared the number of positive breeding sites for Ae. albopictus, the number of larvae of Ae. albopictus per artificial breeding site, the percentage of breeding sites for Ae. albopictus with Ae. aegypti, the ratio between Ae. albopictus and Ae. aegypti and the occurrence of other species sharing the breeding site with Ae. albopictus.

\section{RESULTS}

In January 2014, Aedes albopictus was present only in two cities out of the 24 sampled (Figure 1, Table 1). Taking the total number of culicine collected in tire deposits (1772), Ae. aegypti, Cx. quinquefasciatus (Say, 1823) and Ae. fluviatilis (Lutz, 1904) were the most abundant species, corresponding to $89.6 \%$ of the sample (Table 1), so Ae. albopictus represented $5.6 \%$ of the total sample. The rest of the species were: Lutzia bigoti (Bellardi, 1862), Toxorhychites sp., Cx. eduardoi (Casal \& Garcia, 1968), Cx. coronator (Dyar \& Knab 1906), Cx. tatoi (Casal \& Garcia, 1971), Cx. maxi (Dyar, 1928) and Cx. apicinus (Philippi, 1865).

In March 2015, we collected, in the houses, a total of 2,945 specimens (1,842 in Eldorado and 1,103 in Colonia Aurora) belonging to 11 species of the genera Aedes, Culex, Limatus and Toxorhynchites. Aedes aegypti and Ae. albopictus accounted for $86 \%$ of total individuals. A total of 149 containers were inspected, of which $71(47.6 \%)$ were positive. The relative abundances of these species depended on the town (Pearson's Chi-square $=932.63$, $\mathrm{gl}=2 ; \mathrm{p}<0.0001)$. While in Eldorado Ae. aegypti was the dominant species with a relative abundance of $88.4 \%$, Ae. albopictus accounted for $6.4 \%$ of the individuals caught. On the contrary, in Colonia Aurora both species were dominant, representing $71.4 \%$ of the specimens collected, being Ae. albopictus slightly more abundant $(37.1 \%$ for Ae. albopictus and $34.3 \%$ for Ae. aegypti).

Regarding the comparison between the 1998 study and ours, in 2015, one can observe that although in the first study the number of inspected containers with water was of 2,237 in comparison with 90 in 2015; in the latter the percentage of containers with Ae. albopictus and the number of individuals of this species was higher (Table 2).

\section{DISCUSSION}

The present study extends the austral distribution of Ae. albopictus for Argentina to the municipality of Colonia

Table 2 - Comparison of Ae. albopictus status in Eldorado in 1998 (according to Schweigmann et al. ${ }^{8}$ ) with the status in Eldorado and Colonia Aurora in 2015.

\begin{tabular}{|c|c|c|c|}
\hline \multirow{2}{*}{ Variables/ year } & \multicolumn{2}{|c|}{ Eldorado } & \multirow{2}{*}{$\frac{\text { Colonia Aurora }}{2015}$} \\
\hline & 1998 & 2015 & \\
\hline Inspected containers & 2,237 & 90 & 59 \\
\hline Breeding sites with Ae. albopictus (\%) & $33(1.47)$ & $13(14.44)$ & $15(25.42)$ \\
\hline $\begin{array}{l}\text { Breeding sites with Ae. albopictus/ houses with } \\
\text { Ae. albopictus }\end{array}$ & 1.08 & 1.3 & 1.36 \\
\hline $\begin{array}{l}\text { Number of Ae. albopictus larvae/ breeding sites of } \\
\text { Ae. albopictus }\end{array}$ & 1.43 & 9 & 27.27 \\
\hline $\begin{array}{l}\text { Percentage of breeding sites of Ae. albopicuts with } \\
\text { Ae. aegypti (\%) }\end{array}$ & 85 & 100 & 93 \\
\hline Proportion (Ae. albopictus:Ae. aegypti) & $\approx(1: 10)$ & $\approx(1: 14)$ & $\approx(1: 1)$ \\
\hline \multirow{4}{*}{$\begin{array}{l}\text { Other species that shared the breeding site with } \\
\text { Ae. albopictus }\end{array}$} & Li. durhamii & Li. durhamii & Li. durhamii \\
\hline & Ae. fluviatilis & Ae. fluviatilis & Ae. fluviatilis \\
\hline & Toxorhynchites sp. & & Cx. quinquefasciatus \\
\hline & Culex sp. & & Cx. bidens \\
\hline
\end{tabular}


Aurora ( $\left.27^{\circ} 28^{\prime} \mathrm{S} ; 54^{\circ} 31^{\prime} \mathrm{W}\right), 120 \mathrm{~km}$ of the Southernmost record in the city of Eldorado ${ }^{8}\left(26^{\circ} 24^{\prime} \mathrm{S} ; 5^{\circ} 38^{\prime} \mathrm{W}\right)$. To date, most of the studies on this vector have only indicated its occurrence in the country ${ }^{7,9}$. In the only ecological report, Schweigmann et al. ${ }^{8}$ found low abundances in Eldorado, homogeneously distributed.

After 20 years, Ae. aegypti remains the most abundant species in this city and occurs simultaneously with the Asian tiger mosquito in all breeding sites. Aedes albopictus continues to be found in a smaller proportion, but in Colonia Aurora both species are the most abundant and they present similar abundances. Regarding the species that share breeding sites with Ae. albopictus, Ae. aegypti remains the species with which it coexists mostly, and to a lesser extent with Li. durhamii, Ae. fluviatilis and Culex species.

Based on the present study and other reports that have also monitored the same study $\operatorname{area}^{9}$, the bounded distribution of Ae. albopictus in the province of Misiones is striking, considering that the vector occurs at higher latitudes in Uruguay ${ }^{4}$ and is widely distributed in Southern Brazil, more precisely in Rio Grande do Sul State ${ }^{14}$ that borders the provinces of Corrientes and Misiones. In this context, it is possible that a greater sampling effort on tires is required to detect Ae. albopictus in the cities of Misiones. Brazilian studies indicate that it is the most frequent and dominant species in this type of breeding site ${ }^{15,16}$ so that searching for Ae. albopictus in tires is expected to retrieve positive results.

Despite this, the reported distribution of Ae. albopictus differs from other studies that predicted that this species could be potentially found to the South of the province of Buenos Aires $\left(\approx 38^{\circ} \mathrm{S} \text { Latitude }\right)^{5,17}$. According to Kreamer et al..$^{5}$, one of the most important predictors is the temperature that limits the gonadotrophic cycles of the vector. These studies were based on bibliographic data that investigated the vector survival, information that is unknown for local populations.

Due to the lack of diapause in the South American populations, several studies indicate that the local population of Ae. albopictus could have a tropical origin ${ }^{18}$. It is possible that this attribute influences the distribution of this mosquito. Since warm area insects exhibit a high minimum development threshold temperature ${ }^{19}$, an evaluation of larval development and survival rates of Latin American populations at low temperatures would be necessary to indicate whether temperate zones can affect survival and development. However, the lack of diapause was not a limitation for the expansion of Ae. aegypti, species that also lacks diapause and whose range reaches temperate regions such as the province of Buenos Aires ${ }^{12}$. In this context, it would also be interesting to evaluate other factors that could affect the distribution of the vector in the region, such as eggs mortality, a situation observed in the United States, where eggs of Ae. albopictus have a higher mortality than the ones of Ae. aegypti ${ }^{20}$.

According to the Provincial Institute of Statistics and Census, Province of Misiones ${ }^{21}$, Eldorado is characterized as an urban area, while Colonia Aurora is rural. However, the results of this study differ in part from those observed in the American continent where spatial segregation of both vectors is observed ${ }^{10}$. In our study, in Colonia Aurora, both species were in similar abundances characterizing a co-dominance. According to Braks et al. ${ }^{10}$, Ae. aegypti generally predominates in highly urbanized habitats and Ae. albopictus in rural areas. In that study, they attributed the high abundances of this species in rural environments to a greater competitive advantage compared to Ae. aegypti.

After 20 years since its discovery in the province of Misiones, the reasons for the limited distribution of Ae. albopictus in Argentina remain unknown, considering that it has a great dispersive capacity in other regions of the world ${ }^{2}$. This study demonstrated that Ae. albopictus has not increased its distribution with the speed that was registered in others regions of the world. However, the high abundances in Colonia Aurora and the fact that this species went South in neighboring countries, is warning that this vector has still the potential to expand its geographic niche, posing a risk to the public health in Argentina. For this reason, evaluating the population attributes and interaction with other species and parasites in the region will contribute to understand what factors are affecting the presence and abundance of the vector in the country and to determine the control measures of this vector.

\section{ACKNOWLEDGMENTS}

We thank the staff of the Ministry of Ecology and Natural Resources of Misiones for the quick management in granting the sampling permits in the province, and the municipality of Eldorado for their help.

\section{AUTHORS' CONTRIBUTIONS}

Arturo A. Lizuain participated on the conception, planning, sampling, analysis, interpretation and writing of the work; Marina Leporace participated on the planning, sampling, interpretation and writing of the work; Maria Soledad Santini and María E. Utgés participated on the planning, interpretation and writing of the work; and Nicolás Schweigmann participated on the planning, sampling, analysis, interpretation and writing of the work. All authors approve the final submitted version. 


\section{REFERENCES}

1. Gratz NG. Critical review of the vector status of Aedes albopictus. Med Vet Entomol. 2004;18:215-27.

2. Lounibos LP. Invasions by insect vectors of human disease. Annu Rev Entomol. 2002;47:233-66.

3. Kraemer MU, Sinka ME, Duda KA, Mylne A, Shearer FM, Brady OJ, et al. The global compendium of Aedes aegypti and Ae. albopictus occurrence. Sci Data. 2015;2:150035.

4. Rossi GC, Martinez M. Mosquitos (Diptera: Culicidae) del Uruguay. Entomol Vect. 2003;10:469-78.

5. Kraemer MU, Sinka ME, Duda KA, Mylne AQ, Shearer FM, Barker CM, et al. The global distribution of the arbovirus vectors Aedes aegypti and Ae. albopictus. Elife. 2015;4:e08347.

6. Carvalho RG, Lourenço-de-Oliveira R, Braga IA. Updating the geographical distribution and frequency of Aedes albopictus in Brazil with remarks regarding its range in the Americas. Mem Inst Oswaldo Cruz. 2014;109:787-96.

7. Rossi GC, Pascual NT, Krsticevic FJ. First record of Aedes albopictus (Skuse) from Argentina. J Am Mosq Control Assoc. 1999; $15: 422$

8. Schweigmann N, Vezzani D, Orellano P, Kuruc J, Boffi R. Aedes albopictus in an area of Misiones, Argentina. Rev Saude Publica. 2004;38:136-8.

9. Rossi GC, Lestani EA, D’Oria MJ. Nuevos registros y distribución de mosquitos de la Argentina (Diptera : Culicidae). Rev Soc Entomol Argent. 2006;65:51-6

10. Braks MA, Honório NA, Lourenço-de-Oliveira R, Juliano SA, Lounibos PL. Convergent habitat segregation of Aedes aegypti and Aedes albopictus (Diptera: Culicidae) in southeastern Brazil and Florida. J Med Entomol. 2003;40:785-94.

11. Cabrera AL. Fitogeografía de la república Argentina. Bol Soc Argent Bot. 1971;14:1-50.

12. Zanotti G, De Majo MS, Alem I, Schweigmann N, Campos RE, Fischer S. New records of Aedes aegypti at the southern limit of its distribution in Buenos Aires province, Argentina. J Vector Ecol. 2015;40:408-11.
13. Rossi GC, Almirón WR. Clave ilustrada para la identificación de larvas de mosquitos de interés sanitario encontradas en criaderos artificiales en la Argentina. Buenos Aires: Fundación Mundo Sano; 2004.

14. Cardoso JC, Corseuil E, Barata JM. Culicinae (Diptera: Culicidae) ocorrentes no Estado do Rio Grande do Sul, Brasil. Rev Bras Entomol. 2005;49:275-87.

15. Honório NA, Lourenço-de-Oliveira R. Freqüência de larvas e pupas de Aedes aegypti e Aedes albopictus em armadilhas, Brasil. Rev Saude Publica. 2001;35:385-91.

16. Piovezan R, Rosa SL, Rocha M, de Azevedo TS, Von Zuben CJ. Entomological surveillance, spatial distribution, and diversity of Culicidae (Diptera) immatures in a rural area of the Atlantic Forest biome, State of São Paulo, Brazil. J Vector Ecol. 2013;38:317-25.

17. Benedict MQ, Levine RS, Hawley WA, Lounibos LP. Spread of the tiger: global risk of invasion by the mosquito Aedes albopictus. Vector Borne Zoonotic Dis. 2007;7:76-85.

18. Lounibos LP, Escher RL, Lourenço-de-Oliveira R. Asymmetric evolution of photoperiodic diapause in temperate and tropical invasive populations of Aedes albopictus (Diptera: Culicidae). Ann Entomol Soc Am. 2003;96:512-8.

19. Honěk A. Geographical variation in thermal requirements for insect development. Eur J Entomol. 1996;93:303-12.

20. Juliano SA, O’Meara GF, Morrill JR, Cutwa MM. Desiccation and thermal tolerance of eggs and the coexistence of competing mosquitoes. Oecologia. 2002;130:458-69.

21. Instituto Provincial de Estadística y Censos. Gran atlas de Misiones. Posadas: IPEC; 2015. [cited 2019 Jan 16]. Available from: https://ipecmisiones.org/

22. Argentina. Ministerio del Interior, Obras Públicas y Vivienda. Subsecretaría de Relaciones Municipales.. [cited 2019 Jan 16]. Available from: https://www.mininterior.gov.ar/municipios/ datos-municipio.php 